Volume: 14 Issue: 2 Year: 2017

\title{
The analysis of Basque conflict and ETA in the 1990s: The kidnapping of Miguel Angel Blanco
}

\author{
Sezai Özçelik ${ }^{1}$
}

\begin{abstract}
Since the fall of the Franco's regime in Spain, the Spanish governments have been dealing with the low-intensity conflict in their country, namely the Euskadi Ta Askatusuna (ETA) attacks. This article analyzes the Basque conflict within the framework of the conflict analysis and resolution perspective. First, it highlights the conflict issues among the Basque conflict parties. Second, it clarifies the conflict issues by focusing on kidnapping and assassination done by the ETA during 1990s. The special case of Miguel Angel Blanco who was a local Basque councilman is a case study. In order to shed light on the Blanco case, it is necessary to focus the conflict resolution dynamics of the Basque conflict. Third, the paper aims to examine the Blanco case in terms of conflict issue identification, conflict issue clarification, and conflict cultural analysis perspectives. The issue identification perspective focuses on identity, face, and instrumental issues of the Basque conflict. The issue clarification perspective concentrates on two conflicting parties' perceptions and positions in the conflict. The cultural analysis perspective mainly attempts to analyze the crosscultural differences between ETA and the Spanish government. Based on the analysis of Miguel Angel Blanco, this study concludes that it is necessary to reframe, re-identify and re-clarify the Basque conflict within the framework of conflict and peace studies.
\end{abstract}

Keywords: Basque conflict, conflict analysis, conflict resolution, issue identification and clarification, Euskadi Ta Askatasuna (ETA), cultural analysis.

\section{Introduction}

The Spanish government has been involved in an "ethnic" conflict over territory in the Northern Spain known as the Basque Country. It is known as the Spain - ETA conflict or the Basque conflict. Although it has been a part of the Spanish territory since the Medieval Times, the Basque people who mostly live in Spain consider themselves having the oldest culture and language in all of Europe. In the mid-1930's, the Franco's Fascist regime has been able to control all over Spain after the Spanish Civil War. Franco also claimed that the "long struggle between centralism and regionalism in the country" was ended (Clark, 1980a, p.80). He launched a series of antiregionalist policies in the Basque provinces, including hampering food distribution, disposition of the regional government, and outlawing use of the native Basque tongue, the Euskera. Furthermore, the policy allowed the police to make mass arrests for the use of the Euskera even though the Euskera was used by ordinary people for their normal daily conversations just on the street.

In a reaction to the growing repression of the oppressive Franco regime against the Basque people, a regionalist and anti-fascist movement known as ETA ("Euskadi Ta Askatasuna" or "the Basque Country and Freedom") has been formed from previously less organized student protest and union groups. The ETA members banded all together with the singular goals of the Basque

\footnotetext{
1 Associate Prof. Dr., Çankırı Karatekin University, Faculty of Administrative and Economics Sciences, Department of
} International Relations, sezaiozcelik@gmail.com, sozcelik@,karatekin.edu.tr 
Özçelik, S. (2017). The analysis of Basque conflict and ETA in the 1990s: The kidnapping of Miguel Angel Blanco, Journal of Human Sciences, 14(2), 1058-1069. doi:10.14687/jhs.v14i2.4429

unity and separatism from Franco - controlled Spain. Beginning on July 31, 1959, ETA would have gained "a major impact on Basque and Spanish politics." (Rinehart, 2013, p. 53-75; Clark, 1984, p.27)

During its first decade of existence, ETA was organized around three distinct ideological principles. The first was being an old nationalist theme of emphasis on cultural and linguistic freedom for Basques. Proponents argued that "language was the principle or even the soul of a valid definition for a nation." (Clark, 1984, p.33) These advocates believed that the only way to preserve the Euskadi culture was to establish a separate Basque state. The ETA's second major ideological principle consisted of a series of Marxist-held beliefs. Marxist ETA members stressed the importance of the liberation of the Basque working class and those of all Spanish workers from the industrial oligarchies of Spain, Great Britain, and the United States. In contrast to the strong separatist ETA membership, proponents of Marxism did not necessarily want independence but preferred opposition to the Fascist government, believing that true freedom can only come about with an alliance with the Spanish working class (Ciment and Hill, 1999, p. 1190). The third major ideological theme was influenced by events in the Third World in the 1960s, based on a reaction to the Western European and American colonialism, forging ties with various the Third World Groups such as the Algerians and the Vietnamese (Sullivan, 2015, p. 41). Followers of this ETA ideology were devoted to the ideas laid by the Latin American revolutionary, Che Guevara. This philosophy stated that "if the objective conditions for revolution were not correct, then the revolutionary elite had the obligation to go on the offensive and begin the struggle in order to bring those objective conditions into being" (Clark, 1984, p.32-34).

ETA's first violent direct actions against the government began on July 18 1961, when they attempted to derail a series of trains carrying Franco supporters to San Sebastian to celebrate the 25th anniversary of Franco's victory in the Spanish Civil War (Gomez, 2017, p. 105). Their attempted derail, though unsuccessful, was met with the harsh and swift reaction by Spanish authorities They arrested and tortured more than 100 ETA members, with some members receiving jail sentences of 15 to 20 years (Clark, 1984, p.35). The ETA was included on terrorist lists by the European Union (EU) and the United States. It was a violent secessionist organization.

ETA has taken a part of the Basque nationalist and political movements. The Spanish government has labeled ETA's activities as political violence and terrorism. In the Basque politics, ETA's surrogate political party, Herri Batasuna, has become another main political actor during the post-World War II era. The tactics employed by ETA included bank robberies, exaction of a "revolutionary tax" from targeted Basque businesses, intimidation, sloganeering, public graffiti, kidnapping, assassinations and bombings (Douglass and Zulaika, 1990, p. 238). Up until the end of 1997 when Miguel Angel Blanco was kidnapped and assassinated, ETA had been killed approximately more than 800 people over the forty-year period, and approximately one third of the victims have been civilians (Law, 2009).

In addition, there have been anti-democratic attitudes and behaviors such as police actions in the Basque region against the ETA members. Under principles of the rule of law and democratic state, it is unacceptable to use torture against the detained members of ETA. The Basque National Liberation Movement has thought police actions in 2005 as violence, torture, and state terrorism. ETA members have claimed that they were routinely tortured by the security forces and paramilitary patriotic group during the period of the mid-1980s of "the dirty war" (La guerra sucia).

This study aims to shed light on the Basque conflict and the ETA within the framework of kidnapping and assassination during the period of 1990s. It specifically focuses on the ETA's kidnapping and the assassination of Miguel Angel Blanco who was a local Basque councilman. The Blanco case is the turning point in public opinion for the Basque conflict. It has sent a wave of dislike through Spain. At least six million Spanish people have demonstrated on the streets to protest against the ETA's bloody violence for four days. As a result, some of ETA own members have publicly condemned the killing of Blanco. From that point, ETA no longer believed that it can achieve its goals through violent means. The turning point for the Basque conflict came when the 

Journal of Human Sciences, 14(2), 1058-1069. doi:10.14687/jhs.v14i2.4429

ETA have lost its public support in 1997 when there has been massive public demonstrations and street protests after the death of Miguel Angel Blanco. The growing public dislike against ETA violence has reached its climax because the kidnappings and assassinations have not produced desired effects that forced the Spanish government negotiations. The efficiency of ETA violence has increasingly become in question. Before the Blanco incident, the Basque parties have signed the Pact of Ajurea-Enea in which the main Basque institutions declared their oppositions of ETA using violent tactics on 12 January 1988. It opened the road of the marginalization and isolation of ETA. Also, the close cooperation between Spanish and French security forces resulted in the capture and imprisonment of ETA members in France (Gibbons, 1999, p.24).

After the Miguel Angel Blanco incident, the conflict has reached "the mutually-hurting stalemate" (Zartman and Touval, 1996) for the conflicting parties. First, the research explains negotiation and conflict resolution dynamics in the Basque conflict. Next, this article analyzes how this incident could be a tool for the resolution of conflict by focusing on the conflict issue identification, conflict issue clarification, and conflict cultural analysis. In the third section, the conflict identification examines the Spanish government and ETA instrumental issues as well as face and identity issues. With a holistic approach, this study claims that the Basque conflict should address all three issues: instrumental, face and identity issues. Fourth, the issue clarification perspective concentrates on two conflicting parties' perceptions and positions in the conflict. In the fifth part, the cultural analysis perspective, mainly attempts to analyze the cross-cultural differences between ETA and the Spanish government. The study clarifies three issues by explaining the positions and interests as well as underlying needs. Based on the analysis of Miguel Angel Blanco, it is concluded that it is necessary to reframe, re-identify and re-clarify the Basque conflict within the framework of conflict and peace studies. Last, it suggests some conflict resolution steps not only manages but also transforms the ETA conflict.

\section{Issue Identification}

The issues involved in the Spain - ETA conflict have manifested themselves in 1997 in the kidnapping and assassination of Miguel Angel Blanco, a local Basque country councilman from Ermua. The conflict exists between not two equal parties, but rather between a Western and industrialized European power and a marginalized, ethnic minority and paramilitary group. For this reason, issues have not been negotiated on an even playing field.

The instrumental issues in the 1990s involved in the conflict from the ETA standpoint were: (1) transfer of ETA members and other Basque nationalists, currently being detained in Spanish prisons, into prisons in Pais Vasco (the Basque country); (2) fair and just electoral processes in Pais Vasco; and (3) and the eventual secession of Pais Vasco from Spain. The Spanish government's instrumental interests were the release of all hostages currently being held by ETA and the end of ETA-sponsored violence throughout Spain.

The major characteristics of the relationship between the Spanish government and ETA were paranoia and distrust. Even with Herri Batasuna's significant drop in the polls in Basque elections during the 1990s, ETA claimed that the Spanish government "fixes" the elections in favor of the more moderate PNV (Partido Nacinalista V asco or Basque Nationalist Party) and the heavily Spanish controlled PP (Partido Popular or Popular Party) (Burns, 1997). In a sign of Spanish distrust and paranoia, the government refused to initiate peace talks or discuss settlement with ETA until ETA declares a full and open cease-fire that is "unilateral, permanent and verifiable by the international community" as well as surrenders all arms.

The two central issues in this conflict were the issue of face and the issue of identity. Specifically, this is an issue of perception of the identity of both self and other (Öğretir and Özçelik, 2008). ETA's self-perception was that they are a nation representing Basque people, language, and culture. ETA perceived the Spanish government as an unacceptable and illegitimate colonial power. The Spanish government considered itself a legitimate nation-state with governmental authority over all provinces of Spain, including Pais Vasco. It perceived ETA as simply a criminal terrorist 

Journal of Human Sciences, 14(2), 1058-1069. doi:10.14687/ihs.v14i2.4429

organization, with no support and no legitimacy. Spain feared a loss of face both domestically and internationally if it overtly negotiated and made concessions to a terrorist group dismissing their support in Pais Vasco. Spanish face was attacked because of ETA kidnapping and executions of public officials as well as propagandizing against the Spanish state. The face issue between the Government of Spain and ETA wrecked during the capture and execution of Miguel Angel Blanco.

Miguel Angel Blanco, 29, was a Basque town councilor and low-ranking member of Jose Maria Aznar's ruling the Popular Party (PP) at that time. Blanco was kidnapped by ETA on July 11, 1997 after leaving his home in Ermua. ETA threatened to execute Blanco unless the government met its demand: the government must have transferred 500 ETA inmates to the Basque country prisons by 4 p.m. on July 13, 1997. The government was given a time limit of 48 hours to respond. However, government officials dismissed ETA's demand, saying it would not succumb to blackmail and change policy in the face of a threat (Black, 2010, p. 157). Many Basque nationalist leaders, even those who oppose ETA activities, have also pressed for the transfer of prisoners. This came after numerous outcries that prisoners were mistreated, and in fact tortured in Spanish jails (TAT Report, 1993).

Identity and face issues were salient in this incident. They denoted an individual's concern for the others' and self's presentations, reputation and face. In Blanco's kidnapping, both personal and social identity issues were important. In respect to personal identity, when ETA demanded the government the transfer of 500 jailed rebels to prisons in the Northern Basque region, the government refused to give into what it termed "blackmail." (Murua, 2017).

The social identity issues were more important because of culture and past history (Öğretir, 2017a, 2017b). First, ETA has kidnapped 77 people during its existence. However, it has only set deadlines to execute hostages twice before (Washington Post, 1997, p.A16). In both cases, the threats were carried out. Therefore, ETA had only one choice to save and maintain their image - to kill Blanco. Second, Blanco was abducted because the government had succeeded in freeing Jose Lara, a prison officer who ETA held captive for nearly 18 months (Martínez, Uria, and Arrospide, 2016). ETA had made the same demand for the release of Jose Lara. The government refused the ultimatum because they felt that a concentration of ETA prisoners would pose a threat to security. More importantly, the government refused to succumb to the demands of terrorist groups. In the Lara situation, ETA lost face because government officials freed him before ETA was able to take further action. As a consequence, ETA set a 48-hour deadline for the Blanco kidnapping (Reiss, 2010)

ETA's kidnapping of a Sigma factory manager in Basque country, Berezadi, presented some similarities with the Blanco incident. In the Berezadi kidnapping, Spanish Interior Minister Fraga Iribane took a hard line position - no negotiation with terrorists. The environment surrounding Berazadi appeared to be non-hostile and comfortable until his whereabouts were discovered by the landlady. At this point, ETA quickly convened six members of its ruling committee to decide whether or not to kill Berezadi. At first, the voting was deadlocked between moderates and hardliners. On the third ballot, one of the moderates abstained and the order went out to kill the hostage because failure to do so would have damaged ETA's credibility (Douglas and Zulaka, 1990). Paralleling the Blanco case, two points can be made: (1) ETA followed through on threats of execution when such threats were made, and (2) assassinations could have been random, indiscriminate, and unpredictable.

Collective emotions ran high and created an exceptionally intense reaction to the abduction and the subsequent death of Miguel Angel Blanco. In his hometown, Ermua, 14,000 citizens gathered in memory of Miguel Blanco and in protest of his death. It was a turning point for the Basque conflict. Reactions were intense across Spain, with demonstrations taking place in city and town centers surpassing even those which followed the failed 1981 coup d'etat. Police estimated the crowds in Madrid at nearly one million and in Barcelona at 900,000. Tens of thousands more packed at streets in nearly every major Spanish city. In Bilbao alone, 100,000 people were on the streets to cry against ETA violence (Managanas, 2016). It is estimated that six million people may 
Özçelik, S. (2017). The analysis of Basque conflict and ETA in the 1990s: The kidnapping of Miguel Angel Blanco, Journal of Human Sciences, 14(2), 1058-1069. doi:10.14687/jhs.v14i2.4429

have taken part in the demonstrations across Spain calling for Blanco's immediate release (Whitfield, 2014, p. 83). Messages of condolence were sent from all over the world, including the Vatican and the French government. The leaders of all the political parties in the Basque regional parliament, excluding Herri Batasuna, held an emergency meeting and released a statement saying, "ETA is weaker and more alone today than yesterday, but the society is more United than ever." (New York Times, 1997, p.13)

The emotional issues of this conflict have gone well beyond ETA and the Spanish government. The citizens of Spain; Basque or otherwise, carried and expressed the intense emotional burden over both Miguel Blanco and the conflict in general. While the Spanish government and ETA continued not to engage one another in productive dialogue, the people of Spain were unifying under the banner of "ETA, Basta Ya." That loosely translated from Spanish means "ETA, it is enough. Stop It Already." A slogan was quickly being adopted by several people peace initiatives in Pais Vasco (Magone, 2004, p. 22).

\section{Issue Clarification}

ETA's intentions have not changed for a long time. First, ETA has insisted that Euskera and Euskadi culture should be the dominant in the Basque region. Moreover, the Basque language and culture should have been used in the educational and religious institutions. Second, ETA has intended to free the Basque region from Spanish economic control. Pais Vasco is rich in manufacturing, fishing, and has excellent soil deposits for commercial agriculture. It constitutes a large percentage of Spain's financial base in heavy industrial manufacturing. ETA wants Pais Vasco to take full control over Basque economy from Spain. As a result, these intentions have culminated into ETA's ultimate goal of complete Basque separation from Spain.

ETA's perception of the issues surrounding this conflict is based on their interpretation of what is and is not Basque language, culture, and history. ETA believes that Euskera is the official, national language of Pais Vasco. Using history to justify their logic, ETA affirms Euskera's legitimacy, because its use predates all other European languages. ETA dislikes Spanish control over Basque region what they consider to be a birthright. This perception is an outward expression of the group's anti-colonial ideology (Clark, 1984, p.64-65). ETA has projected the whole of its culture strictly based on the use of its language. The issue of culture and language will be discussed in greater depth below.

ETA's perception of an independent Basque economy follows the same logic as does its argument for language and culture. ETA believes that control of the Basque economy is the right of the Basque people. Although Pais Vasco prospers, economically; ETA believes that it is not the duty of the Basque people to accept and follow Spanish economic policy.

With growing interdependence between Basque and Spanish peoples socially and economically, ETA fears to the total annihilation of the Basque identity through assimilation. This fear is compounded by a growing sense among ETA that the organization is dwindling and could soon cease to exist. ETA's insistence on direct confrontation with the Spanish government, in the pursuit of secession, has caused internal rifts in the organization and subsequent departure of members (Zirakzadeh, 1977, p.171).

On the other side of the conflict lies the Spanish government whose intentions, perceptions and fears have also fallen along the lines of instrumentality, identity and face. Spain's approach to this conflict was not one of facing an adversary, but instead dealing with a criminal. The Spanish Ministry of the Interior issued, in four different languages, including English, a 22-minute counterpropaganda VHS tape titled "The Face of ETA." ETA rebels were labeled as a "gang of terrorist thugs," (Face of ETA, 1997; Pluchinksy, 2015, p. 51-52). Spain has attempted to influence the world's perception of ETA. Spain has adopted a popular, Western government approach to dealing with what they term to be a terrorist activity. A "no negotiating with terrorist" stance has been the predominant philosophy employed by Spain in dealing with ETA (Aviles, 2006, p. 45). The government's intentions were to deal with issues concerning the Basque people, once ETA puts 

Journal of Human Sciences, 14(2), 1058-1069. doi:10.14687/jhs.v14i2.4429

down their arms. Before the Spanish government has engaged in talks, significant concessions must have first been made by ETA, specifically surrendering all arms.

In the 1990s, the Spanish government has felt that it has granted extremely liberal concessions to the Basque region, more so then any other Spanish provinces. In 1978, the Spanish government ratified a new constitution making all regional languages co-official with Spanish in each language's respectful region. The Spanish Ministry of Education has since supported Basque language schools financially and has established obligatory Euskera instruction in the Basque provinces of Vizcaya and Guipdzcoa (Clark, 1980a, p.82). In 1980, the Autonomy Statute was enacted, establishing regional government control over schools, language, health care, industry, and police. The Basque region as well as Catalonia are the only two provinces that do not pay a national tax to Madrid. Spain considers their issues with ETA as moot. They have normalized relations with the Basque region and do not consider themselves in conflict with Pais Vasco.

With every "terrorist" attack and violent outburst, Spain feared its citizenry losses personal safety and trust in their government. The rationale for adopting a "zero tolerance" stance against negotiating with terrorists was an underlying fear that engaging in talks would grant ETA legitimacy. Such talk may also have encouraged more acts of violence from ETA or other groups who perceive the government as weak and willing to bow to demands.

In the 1990s, optimism was at an all-time low for the two parties engaged in this conflict. ETA's dwindling membership, lack of funds, and decreasing support in the Basque region has made the organization all the more desperate. ETA's demand for independence was supported by less than $20 \%$ of Basque people and Herri Batasuna has seen its support decline to about $10 \%$ at the polls (New York Times, 1997). The government has remained entrenched in its policy towards ETA and shown no sign of hopeful resolution.

Even though there has been no obvious end in sight for this conflict during the Blanco kidnapping, motivations for both parties have existed for peaceful resolution. If ETA has continued on its path of decreasing membership and loss of support after the Blanco killing, then the organization has been all but gone in a matter of time. During the last decade, ETA has been fighting more for its own survival than the pursuit of its original goals. As long as solutions could have been presented allowing ETA to bow out gracefully while preserving their face and integrity, there should have then existed a motivation for ending the violence. With constant citizen outcry over ending the violence, the government should have had strong motivation in being the antiterrorist movements that have begun advocacy for the reinstatement of the death penalty.

\section{Cultural Analysis}

The conflict between ETA and the Spanish government is not a typical case of crosscultural difference as much as it is one of the different perceptions of the same dominant culture in Spain. The conflict exists among people who share a high - context Mediterranean, Roman Catholic culture. However, the conflicting parties do not share the perception that they are of the same cultural identity. Identity is the fundamental cultural value that creates difference amongst the Spanish government and ETA in the Basque provinces. History plays an important role in the shaping of Mediterranean cultures and is a major factor in the relationship between ETA and the government (Öğretir, 2008). The perception and interpretation of history are important in exploring a cultural analysis of the conflict between ETA and the Spanish government.

The perception of identity and a strong sensitivity to history are the key variables in understanding cultural differences between ETA and the government. Although ETA is citizens of Spain, they do not consider themselves Spanish - they are Basque. Once again Hall offers insight into the nation within the state.

"The paradoxical part of the identification syndrome is that until has been resolved there can be no friendship and no love - only hate. Until we can allow others to be themselves and ourselves to be free, it is impossible to truly love another human being; neurotic and 
dependent love is perhaps possible, but not genuine love, which can be generated only in the self' (Hall, 1981, p. 237 - 238).

What constitutes the differences between who identifies with a Basque identity and the dominant Spanish? Two variables provide the best answer for criteria-language and birthplace. A survey conducted in the 1970's by Spanish sociologist, Salustiano del Campo, concluded that forty percent of the population surveyed in the Basque provinces, Viczaya, Guipúzcoa and Álava, believed that the Basque region was the most important focal point of their self-identification. However, thirty-one percent of the population surveyed claimed that being from Spain was the focus of their identity. There was some difference between native born Basque peoples who believed that speaking the Basque language-Euskera, is the only true determinant of who is Basque and who is not, while others believed that one must be a native-born Basque as well as a Euskera speaker (Clark, 1980b, p. 78). Almost half of the survey respondents of del Compo study revealed that they used Euskera at home and family. 66.9 percent indicated that "all people who lived in the Basque region should learn to speak Euskera." (Clark, 1979, p. 145).

Another important discovery from del Campo's survey pointed to the important role of the perception of history in the ETA - Spanish conflict. Over fifty-three percent of the native born Basque believed that their region was and is persecuted and punished by the Spanish government. This feeling of persecution is one that Basque has encountered since the tenth century. The region has been politically and economically dominated by outside civilizations, after its period as a mountainous tribal region that fiercely resisted encroachers such as the Celts, Romans, Visigoths, Franks and Muslims. The area was widely thought of as uninviting to conquest because of its terrain. As the Kingdom of Navarra gained economic might in the tenth century, political coherence amongst the region was established. But as the Navarrese kingdom slipped into decline, the emerging power on the Iberian peninsula - the Kingdom of Castilla took control of the Basque lands. Throughout the next millennium, a push and pull relationship developed between the Basque and the Castellan, then Spanish governments. Traditionally, the individual provinces of the kingdom enjoyed self-governance within their provincial boundaries. (Clark, 1980a, pp.79-80).

The freedoms given the province declined greatly after the sixteenth century. The need for the Spanish to fully exploit the Basque coastline during its exploration and conquest of the Americas has increased Spanish migration to the region. Also, a new socio-economic class was established, the bourgeoisie, called as juantxos. The juantxos were closely tied to the Spanish vis-avis commerce. This class was highly influenced by the French revolution and enlightenment. The beginnings of class schism developed in the region at this time, pitting agrarian and independent Basque versus urban and Spanish linked merchants and professionals (Taylor, 2002, p. 30). During this time a conflict between regionalism and centralism broke out throughout Spain. The region developed an industrial base and became very important to Spain that was in the midst of losing its empire. The Spanish government deemed it necessary to reverse the regional laws and incorporate the Basque region into its economy. The Basque historical culture of resistance took shape once again. The first Basque nationalist movement began in the 1890's. The movement was heavily populated with people who did not have strong economic ties to the Spanish (Clark, 1980b, p.80) The Spanish Civil War created a temporary regional autonomy in the country. The Spanish people had experienced full of violent conflict through years of dictatorship, class anarchy and revolution Many participants of the meeting of the San Sebastián Pact were later imprisoned as Francisco Franco's Second Spanish Republic reared toward itself dictatorial way. The Basque region lost all of its political autonomy (Beevor, 1982, p.24-26; Casanova, 2010, p.43).

The Basque people have reacted to the new situation at that time by increasing their nationalist spirit. Economic and military defiance to Franco was represented by the creation of the independent Republic of Eurkadi; the significance of history to the culture was not lost on the new republic as oaths were sworn at the aforementioned oak tree in Guarnica (Minahan, 2002, p. 286). The republic was conservative in its politics and excluded participation by any non-Basque. The Basque were labeled as communists by Franco while he appealed to Spain's unifying cultural 
heritage - the Catholic Church. Spanish archbishops accused Basque priests of carrying out acts of war and being the messengers of communism, not God (Beevor, 1982, p.161-162). These were serious accusations in a country that identifies greatly with its Roman Catholic tradition that is the cornerstone of the Mediterranean culture. Years after the Basque forces surrendered to the Franco government, ETA considered Euzkadi to continue to be at war with Franco because they believed that Franco dishonored the agreement (Beevor, 1982, p.170). Franco ordered summary executions of Basque militia. ETA mistrusted the government and deemed it illegitimate. An important reason for the perceived illegitimacy was Franco's forced suppression of Euskera in the region. The language was impermissible in all parts of public life; similarly, traditional Basque names were changed to Spanish ones. This policy continued into the 1950's.

The Roman Catholic Church in Spain together with Vatican permitted Basque vernacular during the Catholic mass in the early 1950's. After 1968, the teaching of the language was permitted in special language schools-Ikastolas. The Spanish government did not encourage the schools, but attendance was high among Basque youths (McNair, 1984, p. 162). Another change was the publication of cultural writing in Euskera, while political works in Euskera continued to be banned.

Despite the legal implications of a return to Euskera use in the region after the 1978 constitutional reinstatement, usage continues to decline. Economic modernization and migration of Spanish peoples to the region were the principal reasons for Euskera's erosion. The region developed industrially and has become an economic dynamo in Spain (Clark, 1980b, p.82). Prosperity brings migration to the region. As a result, more Spanish live in Pais Vasco than ever before. Cultural interactions and transactions with the Spanish population have transformed the region.

Class differences that have been created since the economic boom reflected those of the mercantile age of exploration. ETA's membership and their supporters in the region are typically not from the socio-economically upper classes of Basque society. Scholar, Robert P. Clark, who has studied the Basque extensively, believes that the Basque nationalists have won more than most nationalist movements, e.g. regional autonomy and control of language (Clark, 1980b, p.92). However, it may boil down to the cultural definitions of liberation and victory. Both the Spanish and Basque are proud high-context cultures which have a long-term conception of time.

\section{Conclusion: Conflict Resolution Concerns}

In order to be able to make headway towards resolution of this conflict, it is necessary to reframe the issues from what they appear to be to a new perception focusing on the transformation of this conflict. As mentioned previously, the instrumental issues that ETA claims are central to this conflict have generally been addressed and resolved by the Spanish government. It is more important to focus on why ETA feels compelled to continue armed insurrection. Some of the reasons why ETA has continued in its struggle at that time were as follows: (1) There is a strong sense of distrust with the government, regardless of changes in policy. (2) ETA continues to claim that Spain violates the human rights of incarcerated ETA members. (3) ETA considers themselves the sole defender of Basque culture. (4) There have been no options presented to them to deescalate the conflict and reenter society.

It has been made clear that in order for this conflict to end, talks must be engaged between the conflicting parties. This has not, and it is predicted that happened in an overt matter. The opportunity for open communication has existed for numerous years within the Spanish and regional Pais Vasco parliaments. Herri Batasuna, moderate Basque nationalist parties, and Partido Popular's representatives in Parliament. All parties in the conflict have ignored opportunities for open engagement because of their intractable and deep-rooted positions.

Regardless of the positions assumed by both the Spanish government and ETA, there has been an overt call for peace by a nationwide, popular movement. People throughout Spain, and especially in Pais Vasco, have demonstrated to meet their basic human needs, namely security and identity to stop the violence. Both the government and ETA recognize the existence and potential 
of such a popular movement. However, both groups were misguided in their interpretation of popular sentiment. The Spanish government has chosen to attempt to garner support by vilifying ETA and justifying government policy with regards to ETA (Face of ETA, 1993). Conversely, ETA believed that the outpour of public sentiment was, in fact, a show of support for the separatist's movement. In protest of the conviction of Herri Batasuna's 23 member directorate, the separatists through the party, were calling a general strike on December 15, 1997 in Pais Vasco (Reuters, 1997).

While each side recognized the potential in the popular movement, they have chosen to attempt to manipulate it rather than tap into its true agenda, namely ending the violence. This movement can be the catalyst towards a resolution of peace. Throughout history, social movements such as the Anti-Vietnam War Movement in the United States, the Pro-Democracy Student Movement in China, and the Democratic Movement in the Philippines have provided the needed political motivation towards the settlement of the conflict.

In order to transformation for this conflict to occur, both parties must realize that they are in the position what Zartman has terms a "mutually-hurting stalemate." This occurs "when one side realizes that it is unable to achieve its aims, resolve the problem, or win the conflict by itself; it is completed when the other side reaches a similar conclusion." (Zartman and Touval, 1996, p.450451; Ozcelik, 2013). ETA was faced with the distinct possibility of being wiped out without ever achieving its goal of secession. Similarly, the Spanish government faced increased possibility of more violence and hostage-taking and a dissatisfied voting public. If action was not taken, the conflict might have escalated and more lives might have been lost.

Negotiations have begun between the government and ETA, but not initially over instrumental issues. Instead, early talks should have focused on building a foundation for the restoration of the mutual face as well as a transformation from distrust into trust. In order to accomplish this goal, a third party is necessary as a go-between and to enhance trust-building. In the past, the Vatican and the Roman Catholic Church have been viable third parties in the BasqueSpanish conflict. The Church can act as a unifying agent between the two parties, building on their existing religious ties. Before the assassination of M. Angel Blanco, ETA and the Spanish government had held peace talks twice. First, the Socialist government of Felipe Gonzalez had talked with the ETA representatives in Algeria in 1989. Second, the Conservative government of Jose Maria Aznar had met with the ETA members in Switzerland in 1998. Both of these talks had been held in secret and had been unsuccessful. The assassination of M. Angel Blanco has mobilized more than six million people not only all over Spain but also in the Basque regions. The crowd has chanted "Vascos Si, ETA No" ("Basque Yes, ETA No.") (Randle, 2003, p. 165). This is known as "The Spirit of Ermua." (Beck, p. 217).

The negotiation between the ETA and the Spanish government has had some difficulties during the 1990s. Both conflicting parties have had deep distrust against each other. They also perceived the conflict from different perceptions. ETA and Batasuna have seen conflict from political-military perspective and insisted on structured negotiations and political agreement. The Spanish governments have perceived ETA as the terrorist organization and any peace process may be seen as 'surrender'. The ceasefires have perceived as "face-saving exit" strategy for ETA. But for the government, they would like to erase ETA from the Spanish political scene (Whitfield, 2014, p. 160).

In the 1990s and the 2000s, some trust-building initiatives have been mutually engaged factfinding missions with a nonpartisan, third-party expert to observe both elections and prison conditions. These initiatives could have gone a long way towards building a level of security and cooperation between the two parties. It was hoped that through this process, the issue of secession became completely moot to both parties. On top of these concerns, there must have been constructive talks concerning the potential re-entry of ETA members into civil society. These were several potential issues that could have been addressed without ever discussing the need for secession while still working towards resolution of the conflict. 

Journal of Human Sciences, 14(2), 1058-1069. doi:10.14687/ihs.v14i2.4429

In order for talks to be successful and these potential initiatives to come to being, a proper environment must have first been established. The environment must have been conducive to trust-building and cooperation. It was felt that the only way to achieve peace and negotiation atmosphere was: (1) ETA's guarantee to halting any further acts of violence and aggression, (2) Suspension of government policy of "non-negotiation" with terrorists, and (3) negotiations must be held in a closed setting (without media or public interference).

In studies of negotiation and conflict resolution, much attention is mostly paid to the role of government actors, political party leaders, and sometimes international mediators. There have been other organizations which may have had the influence on the Basque peace processes. The Basque Labour Union (LAB) and the pacifist organization, Elkarri/Lokarri, have also been a significant contributor to the Basque conflict resolution dynamics. It has five guiding principles: "non-violence and human rights, dialogue and agreement, democratic rules and the consultation of society, respect for the plurality and diversity of public opinion, and support for constructive contributions" (Elkarri, 2012).

All conflicting parties and actors have come together in different times and places to negotiate and mediate the final peace agreement. After each attempt to reach a negotiated solution to the Basque conflict has failed, there has been an escalation of violence, especially kidnapping and assassinations. In escalation and de-escalation cycle of conflict, when conflicting parties has intensified violence with bombings and assassinations, public opinion has initiated campaigns, demonstrations, and street marches to support a negotiated peace settlement between the Spanish Government and ETA. In addition, violent conflicts in other parts of the world have been resolved through dialogue and negotiation that may positively affect the Basque peace process since lessons have been learned from them. The problem of separatist political violence cannot be found a solution based solely on the force by using the police and security forces. The solution to the Basque conflict could be only based on justice and peace with dialogue and negotiation. The most important step between the conflicting parties is to take the Basque conflict from violence cycle of the streets to the table of political negotiations. Peaceful and democratic solution to the conflict must include the accommodation of the rights of all those involved. For ETA, face-saving issues have been important because it should not have lost its legitimacy among its own sympathizers.

This conflict has had the potentials for resolution. Fortunately, the potential for a neverending and mutually destructive struggle has decreased in the last ten years. Acknowledgment of any past wrongs and harm done by both sides has been an essential step in the transformation of this conflict as well as the desire to move forward together for peaceful future. The objective of resolution was to validate all conflicting issues for each party and to create a new relationship based on trust and the ability to deal with differences peacefully. The prolonged negotiations have moved ETA to accept "the definite end of its armed activity" in 2011. However, the positive peace requires the absence of structural and cultural violence that can be only achieved by post-conflict and post-accord peace building and conflict transformation. It is still early to declare that the Basque conflict is ended.

\section{References}

Aviles, Juan (2006). Experiencing Terrorism in Spain: The Case of ETA, In Samuel Peleg and Wilhelm Kempf (eds.), Fighting Terrorism in the Liberal State: An Integrated Model of Research, Intelligence and International Law, Berlin: IOS Press, 40-48.

Beck, Jan Mansvelt (2005). Territory and Terror: Conflicting Nationalisms in the Basque Country, New York: Routledge.

Beevor, Anthony (1982) The Spanish Ciwil War, New York: Peter Bedrick Books.

Black, Stanley (2010). Spain Since 1939, New York: Palgrave.

Burns, Tom. (1997) "Could ETA follow the IRA?", The Tablet, July 26, 1997, www.thetablet.co.uk/leader.cgi 
Özçelik, S. (2017). The analysis of Basque conflict and ETA in the 1990s: The kidnapping of Miguel Angel Blanco, Journal of Human Sciences, 14(2), 1058-1069. doi:10.14687/jhs.v14i2.4429

Casanova, Julian (2010). The Spanish Republic and Civil War, Translated by Martin Douch, Cambridge University Press, Cambridge: UK. Date: 12 July 2012 http://f3.tiera.ru/1/genesis/570-

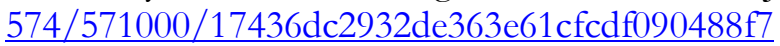

Ciment, James and Kenneth Hill, (1999). Encylopedia of Conflicts Since World War II, vol. 1- 2, London: Routledge.

Clark, Robert P. (1979) The Basques: The Franco Years and Bebind, Reno, Nevada: University of Nevada Press.

Clark, Robert P. (1980a) "Basque Nationalism", In Charles R. Foster (Ed.), Nations Without a State: Ethnic Minorities in Western Europe, New York: Praetor Publishers.

Clark, Robert P. (1980b) "Euzkadi Basque Nationalism in Spain Since the Civil War", In Charles R. Foster (Ed.), Nations Without a State: Ethnic Minorities in Western Europe, New York: Praeger Publishers.

Clark, Robert P. (1984) The Basque Insurgents: ETA, 1952- 1980. Madison, WI: University of Wisconsin Press.

Douglas, William A and Joseba Zulaka, (1990) "On the Interpretation of Terrorist Violence: ETA and the Basque Political Process.", Society for Comparative Study of Society and History, vol. 32, no.2, 238257.

Elkarri, http://www.elkarri.org/en/textos/quienes2.php , Date: 12 July 2012. "Face of ETA." (1997). Spanish Ministry of the Interior. Embassy of Spain Video.

Gibbons, John (1999). Spanish Politics Today, Manchester: Manchester University Press.

Gomez, Javier (2017). "The practice of killing: perpetrators and accomplices", In Rafael Leonisio, Fernando Molino and Diego Muro (Eds.), ETA's Terrorist Campaign: From Violence to Politics 1968-2015, London: Routledge, 103-125.

Hall, Edward T. (1981). Beyond Culture, New York: Doubleday Publishers.

Law, Randall D. (2009). Terrorism: A History, Cambridge: Polity Press.

Magone, Jose M. (2004). Contemporary Spanish Politics, $2^{\text {nd }}$ ed., London: Routledge.

Managanas, Nicholas (2016). Las dos Espanas: Terror and Crisis in Contemporary Spain, UK: Sussex Academic Press.

Martínez, T Ramírez de la Piscina, I Murua Uria, P Idoiaga Arrospide (2016): "Press coverage of Basque conflict (1975-2016): Compilation of attitudes and vicissitudes". Revista Latina de Comunicación Social, 71, 1007-1035. http://www.revistalatinacs.org/071/paper/1132/RLCSpaper1132en.pdf

McNair, John M. (1984). Education for a Changing Spain, Manchester: Manchester University Press.

Minahan, James (2002). Encylopedia of Stateless Nations: Ethnic and National Groups around the World, Vol. 1: $A-C$, Westport, CT: Greenwood Press.

Murua, Imanol (2017). Ending ETA's Armed Campaign: How and Why the Basque Armed Group Abandoned Violence, New York: Routledge.

Ozcelik, S. (2013). Border Creation in Cyprus: Contested History and the Psychodynamic Perspective of Vamik Volkan, Peace and Conflict Review, Summer 2013, vol. 7, no. 2, pp. 1-11. http://www.review.upeace.org/images/pcr7.2.pdf

Öğretir, A. D. (2017a). “Aggression Theories Revisited: Lorenz's Neoinstinctivism, Wilson’s SocioBiology and Skinner's Behavioral Theories", Journal of Asian Scientific Research, Vol. 7, No. 2, pp. 38-45. http://www.aessweb.com/pdf-files/JASR-2017-7(2)-38-45.pdf

Öğretir, A. D. (2017b). "Explanation and Understanding of Human Aggression: Freudian Psychoanalytical Analysis, Fromm's Neo-Freudian Perspective, and Bandura's Social Learning Theory", International Journal of Social Science and Economic Research, vol. 2,no. 1, January 2017, pp. 2151-2164. http://ijsser.org/uploads/ijsser 02 133.pdf

Ögretir, A. D. (2008). “The Relationship Between Culture and the Conflict Resolution Styles: A Survey Method and a Statistical Analysis" Middle-East Journal of Scientific Research, 3 (2): 96-104, http://www.idosi.org/mejsr/mejsr3(2)/9.pdf

Öğretir, A. D. ve S. Özçelik. (2008). "The Study Of Ethnocentrism, Stereotype and Prejudice: PsychoAnalytical And Psycho-Dynamic Theories" Journal Of Qafqaz,University, 24 Fall 2008, 236-244. 
Özçelik, S. (2017). The analysis of Basque conflict and ETA in the 1990s: The kidnapping of Miguel Angel Blanco, Journal of Human Sciences, 14(2), 1058-1069. doi:10.14687/jhs.v14i2.4429

Pluchinksy, Dennis A. (2015). "Ethnic Terrorism and Insurgencies", In Albrecht Schnabel and Rohan Gunaratna (Eds.), Wars from Within: Understanding and Managing Insurgent Movements, London: Imperial College Press, 33-59.

Randle, Janice W. (2003). Issues in Spanish Speaking World, Westport, CT: Greenwood Press.

Reiss, Mitchell B. (2010). Negotiating with Evil: When to Talk to Terrorists, New York: Open Road Media.

Reuters Wire Service, "ETA political wing calls for Basque general strike.", San Sebastian, Spain. December 1, 1997.

Rinehart, Christine Sixta, (2013). Volatile Social Movements and the Origins of Terrorism: The Radicalization of Change, Lanham: Lexington Books.

Sullivan, John, (2015). ETA and the Basque Nationalism: The Fight for Euskadi 1890-1986, 2nd ed., London: Routledge.

Taylor, Robert E, (2002) An Examination of Intra-Group Divisions Among the Basques in the Nineteenth and Twentieth Centuries, Unpublished Master Thesis, Virginia Polytechnic Institute and State University, April 30, 2002. Date: 12 July 2012. http://scholar.lib.vt.edu/theses/available/etd-05102002-155009/unrestricted/Thesis.PDF

Torturaren Aurkako Taldea (TAT) Report, 1993 'Torture in Centers of Detention Objectives.' Euskal Herria Journal, 1993 report. www.easynet.co.uk/cam/censorship/ehj/html/torture.html

The New York Times, July 14, 1997. Protests Follow Death of Official Kidnapped by Basque Rebels, http://www.nytimes.com/1997/07/14/world/protests-follow-death-of-official-kidnapped-bybasque-rebels.html

The Washington Post, July 14, 1997, ETA Killing Provokes Spaniards to Violence, https://www.washingtonpost.com/archive/politics/1997/07/14/eta-killing-provokesspaniards-to-violence/bdd7d265-d0de-41aa-ae3c-2e20d0159a39/?utm term=.c4ea8ad4563a

Whitfield, Teresa. (2014). Endgame for ETA: Elusive Peace for the Basque Country, Oxford: Oxford University Press.

Zartman, I. William, and Saadia Touval. (1996) "International Mediation in the Post- Cold War Era." In Chester A. Crocker, Fen Osler Hampson and Pamela Aall (Eds.), Managing Global Chaos: Sources of and Responses to International Conflict, Washington, DC: United States Institute of Peace Press, 445-462.

Zirakzadeh, Cyrus E. (1977) A Rebellious People: Basques, Protests, and Politics. Reno, NV: University of Nevada Press. 